\title{
Honey bee colonies provided with natural forage have lower pathogen loads and higher overwinter survival than those fed protein supplements
}

\author{
Gloria DeGrandi-Hoffman ${ }^{1}$, Yanping $\mathrm{CHEN}^{2}$, Raul Rivera ${ }^{1}$, Mark CArroll ${ }^{1}$, \\ Mona Chambers ${ }^{1}$, Geoffrey Hidalgo ${ }^{1}$, Emily Watkins de JONG ${ }^{1}$ \\ ${ }^{1}$ Carl Hayden Bee Research Center, USDA-ARS, 2000 East Allen Road, Tucson, AZ 85719, USA \\ ${ }^{2}$ Bee Research Laboratory, USDA-ARS, Beltsville, MD 20705, USA
}

Received 29 April 2015 - Revised 14 July 2015 - Accepted 22 July 2015

\begin{abstract}
Malnutrition is a major cause of colony losses. In managed hives, bees are fed protein supplements (PS) during pollen shortages. If bees were provided with natural forage instead of PS, would they have lower pathogen levels and higher queen and colony survival? We addressed this question by either providing colonies with forage (Brassica rapa - rapini) or feeding them PS from November to February. Soluble protein concentrations in the PS were lower than the rapini pollen as were levels of most amino acids. Nurse bees digested less of the protein in PS than the pollen. Hemolymph protein titers in nurse bees and colony growth did not differ between those fed PS or foraging on rapini. However, colonies fed PS had higher levels of black queen cell virus and Nosema and greater queen losses, indicating that natural forage might improve overwintering survival.
\end{abstract}

pollen nutrition / digestion / amino acids / Nosema / viruses

\section{INTRODUCTION}

The health and longevity of individuals and the growth of populations depend on the availability and nutritional value of food. The nutritional needs of honey bees are met with nectar and pollen. Nectar provides carbohydrates, and pollen supplies protein and all other nutrients (Brodschneider and Crailsheim 2010). Pollen is essential for colony growth, but when it is unavailable, managed hives are fed protein supplements (PS) (Nabors 2000; Mattila and Otis 2006; DeGrandi-Hoffman et al. 2008). Colonies usually are fed PS in the spring when pollen stores are low, and flowering plants and foraging weather are inadequate to support vigorous brood rearing.

Corresponding author: G. DeGrandi-Hoffman, Gloria.Hoffman@ARS.USDA.GOV

Manuscript editor: Stan Schneider
However, feeding PS in fall and through the winter has become increasingly common in the US especially for hives that pollinate early crops such as almonds.

Recently, land managers have been encouraged to plant bee forage to provide pollen for colonies used in almond pollination (http:// www.almonds.com/newsletters/outlook/fall-timeplant-bee-forage). Do these plantings improve colony health and survival to greater degree than those receiving adequate amounts of PS? Studies comparing PS with pollen fed as patties indicate that they are equivalent in palatability (DeGrandiHoffman et al. 2008), hypopharyngeal gland development in nurses ( DeGrandi-Hoffman et al. 2010; Peng et al. 2012), hemolymph protein titers (DeJong et al. 2009; Morais et al. 2013), brood production, and colony growth (Saffari et al. 2010). However, viral loads are lower in bees fed pollen than PS ( DeGrandi-Hoffman et al. 2010) perhaps because pollen feeding affects the 
expression of genes associated with metabolic and immune function (Alaux et al. 2010, 2011).

Previous studies comparing PS and pollen were conducted in cages or in colonies for no more than a month. This might not be long enough for differences between pollen and PS to manifest. We compared the effects of feeding colonies PS with providing natural forage (Brassica rapa - rapini) from November to February. This is when colonies are in holding yards prior to almond pollination. We selected rapini because it blooms profusely in the southwestern USA during the fall and winter and is in Brassicacae, a family with highly nutritious pollen (Singh and Singh 1996). We compared the protein and amino acid composition of PS with rapini pollen, estimated protein digestion, and examined the effects of food source on immunity by measuring Nosema and virus titers. We also recorded queen losses and colony growth and survival. We found that PS might not provide all the nutrients needed to maintain low levels of pathogens and prevent queen loss overwinter.

\section{MATERIALS AND METHODS}

Rapini seed (Rapini broccoli Raab var. Quarantina, My Eco Gardens, Colville, WA, USA) was planted at the University of Arizona West Campus Agricultural Facility in Tucson, Arizona, USA (site 1), and the Red Rock Agricultural Facility in Red Rock, Arizona, USA (site 2), during the first week of October, 2013. Fields were seeded with $0.3 \mathrm{~kg}$ per hectare. Bloom began in November.

\section{Colony establishment and measurements European} honey bee (Apis mellifera ligustica) colonies were established with adult bees, brood, a marked laying queen (Pendell Apiaries, Stonyford, CA, USA), and no pollen stores. The colonies had feeders with $30 \%$ sucrose solution during the entire study. Ten hives were established within $0.4 \mathrm{~km}$ of each planting when bloom began. Colonies fed PS were $13 \mathrm{~km}$ away at the Carl Hayden Bee Research Center, Tucson, AZ, USA. Ten colonies each were fed either BeePro ${ }^{\circledR}$ (Mann Lake, Hackensack, MN, USA, diet 1) or MegaBee ${ }^{\circledR}$ (Dadant, Chico, CA, USA, diet 2). The hives had pollen traps (Front porch pollen traps, Brushy Mountain Bee Farm, Moravian Falls, NC, USA) that were checked every 2-
3 days. Trapped pollen was removed as were dead bees and debris behind the trap.

Colony sizes were measured at the start (November 12) and end (February 11) of the study. Areas on both sides of each frame with brood (all stages) were measured using a grid with $5 \mathrm{~cm} \times 5 \mathrm{~cm}$ squares that covered the entire side of a comb. Values from the frame measurements were summed to obtain brood and adult bee estimates for the colony ( DeGrandi-Hoffman et al. 2008). Colonies were inspected monthly for the marked queen. We replaced lost queens with marked mated queens from the same stock. Colonies with less than one frame covered with bees were counted as a colony loss.

Diet consumption Diet 1 was fed as premade patties. Diet 2 patties were made by mixing granulated sugar (sucrose) with water (2:1) and adding MegaBee ${ }^{\circledR}$ powder at a 1:1 weight ratio. The mixture was covered for $12 \mathrm{~h}$ so the powder could absorb the syrup before making patties. All patties were weighed $(113 \mathrm{~g})$ and placed on the top bars of frames. Unconsumed patties were removed weekly throughout the study, weighed to estimate consumption, and replaced with a new patty.

\section{Hemolymph collection and soluble protein analy-} sis We measured hemolymph protein concentrations in five nurse bees (adult workers feeding larvae) from all colonies when the hives were established (baseline protein levels) and at 3-week intervals from November to February using methods described in DeGrandiHoffman et al. (2010, 2013). Hemolymph also was sampled from day 5 larvae (five per colony). Larvae were rinsed in phosphate-buffered saline (PBS) to remove any brood food prior to sampling (Chan and Foster 2008). Hemolymph from five workers or larvae was pooled, and a $1-\mu \mathrm{L}$ sample was added to $99 \mu \mathrm{L}$ of PBS containing $1 \%$ EDTA-free Halt Protease Inhibitor Cocktail (HPIC) (\#78437, Thermo Scientific, Rockford, IL). Samples were stored at $-80^{\circ} \mathrm{C}$ until analyzed using bicinchoninic acid (BCA) protein assay (\#23225, Thermo Scientific). Absorbance was measured at $562 \mathrm{~nm}$ with a Synergy HT spectrophotometer (BioTek Instruments, Inc., Winooski, Vermont). Protein quantitation was estimated using a standard curve generated from serial dilutions of bovine serum albumin.

Soluble protein in pollen, diets, and hindgut Soluble protein in pollen was measured using corbicular 
loads from bees foraging on rapini. We also sampled stored pollen (i.e., beebread) from colonies at both sites. Pollen and beebread samples were pooled and divided into three subsamples for analysis. Soluble protein concentrations in the PS were measured using three random samples from patties of each diet. In all cases, $1 \mathrm{mg}$ of the food source was added to $999 \mu \mathrm{L}$ of PBS with $1 \%$ EDTA-free HPIC and analyzed for total soluble protein as described above using BCA.

As a measure of digestion, soluble protein concentrations in the hindgut contents (ileum and rectum) of nurse bees were measured and compared with concentrations in the PS and pollen. Nurse bees were used because they consume and digest more pollen than older bees (Crailsheim et al. 1992). Hindguts were removed from the bees, and a $1-\mu \mathrm{L}$ sample of the contents was added to $99 \mu \mathrm{L}$ of PBS and $1 \%$ EDTAfree HPIC. Samples from the five bees per colony were combined, and the pooled sample was added to $900 \mu \mathrm{L}$ of PBS with $1 \%$ EDTA-free HPIC. Samples were stored at $-80{ }^{\circ} \mathrm{C}$ until analyzed as above. Digestion was estimated by: soluble protein concentration in hindgut contents/soluble protein concentration in food source.

AA analysis Random samples of pollen, beebread, and PS were taken as described above for soluble protein analysis. Free amino acids (AAs) were quantified by mixing 10-mg portions with $200 \mu \mathrm{L} 0.03 \mathrm{M} \mathrm{HCl}$ to solubilize the free AA, filtering them through a Gilson $200-\mu \mathrm{L}$ filtered pipette tip and centrifuging the sample. The supernatant $(100 \mu \mathrm{L})$ was analyzed with GC/MS using an EZ:faast kit for free physiological AA (Phenomenex Inc., Torrance, CA, USA).

All analyses were conducted on an Agilent model 7890 GC (Agilent, Palo Alto, CA, USA) coupled to a 5975 quadrupole Mass Selective Detector (MSD) operated in Selected Ion Monitoring mode. A $1.0-\mu \mathrm{L}$ derivatized sample was injected in split mode (Agilent 7693 Autosampler Injection System) and separated on a Zebron ZB-50 capillary column (30-m length, 0.25-mm ID, and $0.25-\mu \mathrm{m}$ film thickness). A deactivated borosilicate single taper glass liner (SGE Focus Liners) was used to minimize sample loss. Injector temperature was $250{ }^{\circ} \mathrm{C}$, with helium as the carrier gas at a flow rate of $1.2 \mathrm{~mL} / \mathrm{min}$. Initial oven temperature $\left(110^{\circ} \mathrm{C}\right)$ was held for $1 \mathrm{~min}$, then ramped up at $30^{\circ} \mathrm{min}$ to $320^{\circ} \mathrm{C}$, and held for $5 \mathrm{~min}$. AAs were identified and quantified by comparing peaks against known retention times and characteristic mass fragments $(\mathrm{m} / \mathrm{z})$ of derivatized AA standards. We detected and quantified nine essential (essential amino acid (EAA)), six conditional (essential in times of stress), and five nonessential AAs (Nelson and Cox 2012).

Nosema levels At the start and end of the study, 25 bees per colony were collected from honey frames and stored in alcohol (Smart and Sheppard 2012; Travers et al. 2012). The samples were divided into groups of five bees. Abdomens were removed, placed in a mortar with $5 \mu \mathrm{L}$ of ultra pure water, and crushed with a pestle. A 1- $\mu \mathrm{L}$ sample was pipetted into a hemocytometer and covered with a glass slip. Nosema spores (presumably Nosema ceranae spores as Nosema apis is not readily detectable in apiaries) were counted at $\times 40$ magnification and converted to total spores per bee using methods described in Fries et al. (2013). The process was repeated for each group of five bees. The percentage of groups with spores and the total number counted in all groups were used as estimates for the colony.

Virus titers Colonies were sampled (five nurse bees per colony) after foraging on rapini or fed PS for four brood cycles. All samples were snap frozen in liquid nitrogen and stored at $-80^{\circ} \mathrm{C}$ until analyzed for black queen cell virus (BQCV), deformed wing virus (DWV), Israeli acute paralysis virus (IAPV), Kashmir bee virus (KBV), and Sac brood virus (SBV) using methods described in Chen et al. (2005). Virus levels were quantified using the comparative $\mathrm{Ct}$ method ( $\Delta \Delta \mathrm{Ct}$ method) that is based on the number of cycles needed to generate a fluorescent signal above a predefined threshold. The average $C t$ value $(\Delta \mathrm{Ct})$ of each virus was normalized using the $\mathrm{Ct}$ value for housekeeping gene $\beta$-actin $\left(\Delta \mathrm{Ct}=\left(\right.\right.$ Average $\left.\mathrm{Ct}_{\text {target } \mathrm{x}}\right)-\left(\right.$ Average $\left.\left.\mathrm{Ct}_{\beta \text {-actin }}\right)\right)$. The group with the lowest $\Delta \mathrm{Ct}$ was chosen as a calibrator. The $\Delta \mathrm{Ct}$ value of each group was subtracted from the $\Delta \mathrm{Ct}$ of the calibrator to generate $\Delta \Delta \mathrm{Ct}$. The virus concentration in each treatment group was calculated using the formula $2^{-(\Delta \Delta \mathrm{Ct})}$ and expressed as an $n$-fold difference relative to the calibrator.

Statistical analysis All data were evaluated for normality and homogeneity of variance prior to analysis. Protein and individual AA concentrations were compared among food sources with one-way analysis of variance (AOV). Repeated measures AOV was used to compare PS consumption and soluble protein 
concentrations in the hemolymph and hindguts. Initial Nosema spore counts were compared among treatments using log transformation followed by AOV. Nosema counts were converted to proportional change (final spore count/initial spore count) and compared among treatments using AOV. Nosema infection can interfere with digestion (Malone and Gatehouse 1998; Dussaubat et al. 2012), so we tested for a correlation between final spore count in a colony and proportion of undigested protein in the hindgut of bees from that colony. Colony size comparisons were made using AOV with the proportional population change (ending/starting population size) as the test statistic. The proportions of queens and colonies lost during the study were compared using ztests. Statistical analyses were conducted using Minitab (Minitab Inc, State College, PA, USA) and SPSS (Field 2005).

\section{RESULTS}

Protein and AA analyses Soluble protein concentrations did not differ between sites or diets, so values for each food source were combined. PS had significantly lower soluble protein levels than pollen or beebread $\left(F_{2,26}=7.08, P=0.004\right)$ (Figure 1).

We detected 20 AAs, with proline having the highest concentration (pollen and beebread) and methionine and serine the lowest (Figure 2). Individual EAA concentrations differed significantly among the food sources in all cases except isoleucine and valine (Table I). Histidine, lysine, and

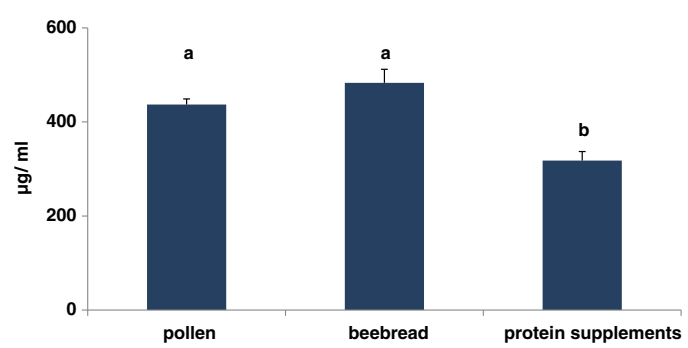

Figure 1. Average concentration $( \pm \mathrm{SE})$ of soluble protein in rapini pollen, beebread, and two protein supplements extracts. Protein concentrations of the supplements did not differ, so data were combined. Averages with the same letter are not significantly different as determined by an analysis of variance followed by a Tukey's multiple comparison test $\left(F_{2,26}=7.08, P=0.004\right)$. threonine concentrations were higher in pollen or beebread than PS. Leucine, lysine, methionine, and threonine concentrations were higher in beebread than pollen. In general, diet 1 had the lowest concentrations of EAA.

Of the seven conditional AAs, cysteine and proline concentrations were significantly higher in pollen and beebread than in either PS. Nonessential AA concentration did not differ among the food sources except for asparagine, which was highest in pollen and beebread and lowest in diet 2 .

Consumption There was no difference between diet 1 and 2 consumptions $\left(F_{1,15}=0.184, P=\right.$ 0.67). Colonies consumed an average of $66.4 \pm$ $4.6 \mathrm{~g}$ of diet 1 and $63.6 \pm 3.5 \mathrm{~g}$ of diet 2 per week.

Soluble protein concentrations in bees Baseline hemolymph protein concentrations did not differ among the treatment groups $\left(F_{3,36}=1.24, P=\right.$ $0.3)$. The concentrations in nurse bees $\left(F_{3,30}=\right.$ $0.196, P=0.898)$ and larvae also did not differ among treatments $\left(F_{3,31}=1.28, P=0.3\right)$ after feeding on PS or pollen for four brood cycles.

Soluble protein concentration of hindgut contents was significantly higher in bees feeding on PS compared with pollen or beebread $\left(F_{3,29}=\right.$ 90.6, $P<0.0001$ ) (Figure 3 ). The contents contained about $65 \%$ of the soluble protein in the PS compared with $30 \%$ of the pollen or beebread.

Nosema spore counts Colonies fed PS, particularly diet 1 , had the greatest increases in samples testing positive for Nosema $\left(F_{3,34}=5.19, P=\right.$ $0.005)$ and the highest average number of spores per colony $\left(F_{3,34}=4.10, P=0.014\right)$ (Figure 4). There was a significant correlation between final spore counts for the colony and the concentration of undigested protein in the hindgut of bees from those colonies (Pearson correlation $=0.445, n=35$, $P=0.007$ ).

Virus titers Of the viruses we screened for, DWV and $\mathrm{BQCV}$ were detected at the highest titers and with the greatest frequency (Figure 5). BQCV titers had the greatest fold increases in colonies fed PS and lowest in those foraging on rapini. 

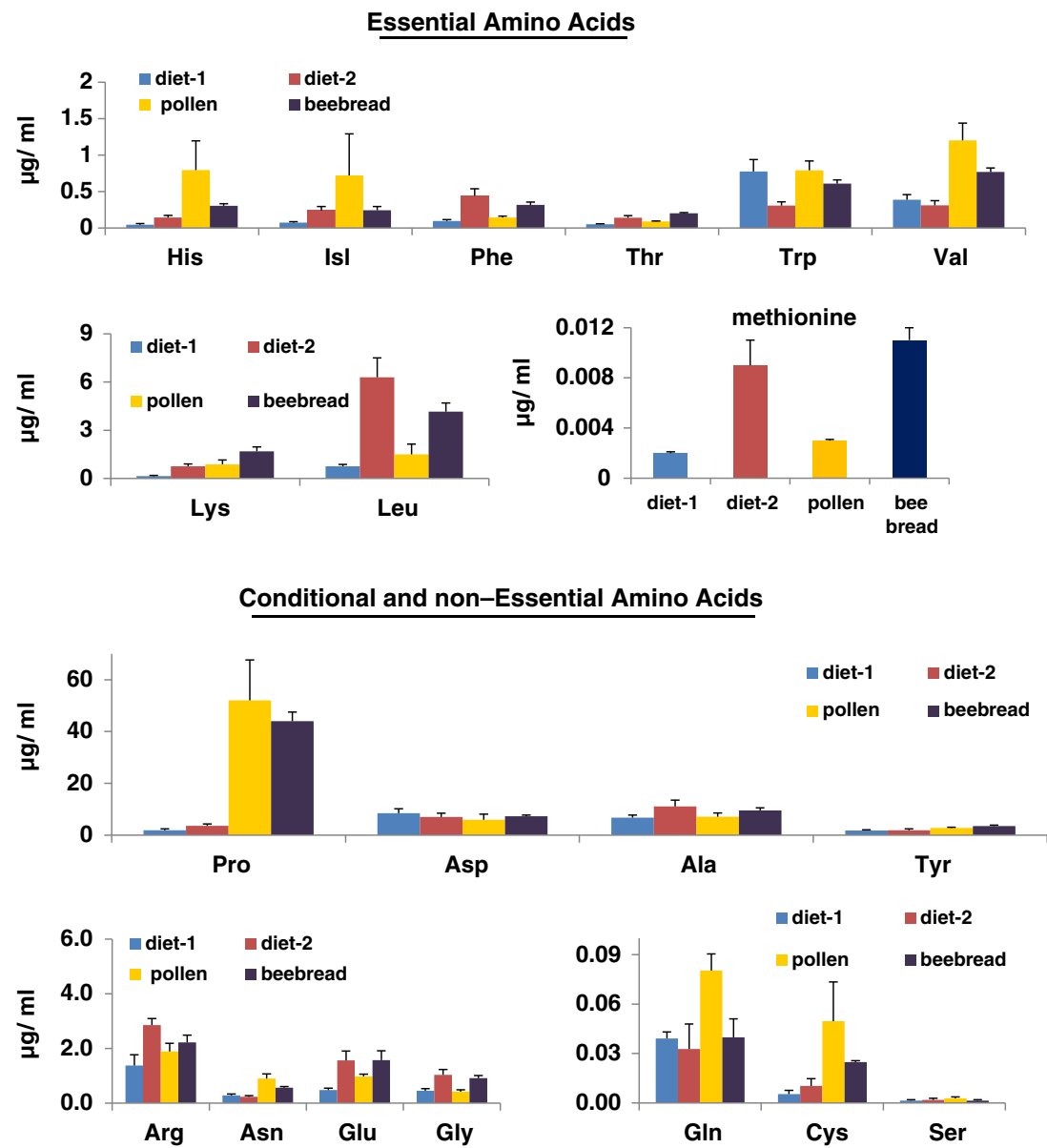

Figure 2. Average amounts $( \pm \mathrm{SE})$ of free amino acids per milligram of two different protein supplements (diet 1 and diet 2), rapini pollen, and beebread extracts.

There were no clear effects of diet on DWV levels.

Colony growth Colony sizes at the start of the study did not differ among treatment groups (adult populations: $F_{3,36}=0.13, P=0.94$; frames of brood: $\left.F_{3,36}=0.42, P=0.74\right)$. Colonies averaged $4.0 \pm 0.3$ frames of bees (approx. 10,024 \pm 250 adults) and $1.8 \pm 0.1$ frames of brood. At the end of the study, populations sizes of surviving colonies were similar to when they began and did not differ significantly among treatment groups (adult bees: $F_{3,27}=0.86, P=0.47$, frames of brood: $\left.F_{3,27}=0.85, P=0.48\right)$.

Queen and colony survival Queen losses were highest among colonies fed diet 1 (z-score $=1.84$,
$P=0.03$ ) (Figure 6). Colony mortality also was higher in those fed PS than foraging on rapini, but the differences were not significant (z-score $=1.4$, $P=0.07)$.

\section{DISCUSSION}

This study compared the nutritional value of two PS with rapini pollen and measured the effects on pathogen loads and colony survival. Both PS had less-soluble protein than pollen and beebread and less was digested. Many AA concentrations also were lower in the PS. Despite the nutritional differences, hemolymph protein titers and population sizes of surviving colonies did not differ among the treatments. However, the 
Table I. Amino acid concentrations found in two protein supplements (diets 1 and 2), rapini pollen and beebread extracts.

\begin{tabular}{llllll}
\hline Amino acid & Diet 1 & Diet 2 & Pollen & Beebread & $F_{3,8}, P$ value \\
\hline Essential & & & & & \\
Histidine & $0.04 \mathrm{c}$ & $0.14 \mathrm{~b}$ & $0.4 \mathrm{a}$ & $0.3 \mathrm{a}$ & $28.5,<0.0001$ \\
Isoleucine & 0.07 & 0.24 & 0.72 & 0.72 & $0.94,0.45$ \\
Leucine & $0.76 \mathrm{~b}$ & $6.31 \mathrm{a}$ & $1.53 \mathrm{~b}$ & $4.15 \mathrm{a}$ & $11.52,0.003$ \\
Lysine & $0.14 \mathrm{~b}$ & $0.75 \mathrm{~b}$ & $0.87 \mathrm{~b}$ & $2.66 \mathrm{a}$ & $19.32,0.001$ \\
Methionine & $0.002 \mathrm{~b}$ & $0.009 \mathrm{a}$ & $0.003 \mathrm{~b}$ & $0.011 \mathrm{a}$ & $22.7,<0.0001$ \\
Phenyalanine & $0.01 \mathrm{c}$ & $0.44 \mathrm{a}$ & $0.14 \mathrm{bc}$ & $0.32 \mathrm{ab}$ & $8.29,0.008$ \\
Threonine & $0.05 \mathrm{c}$ & $0.14 \mathrm{~b}$ & $0.09 \mathrm{bc}$ & $0.23 \mathrm{a}$ & $17.5,0.001$ \\
Tryptophan & $0.78 \mathrm{a}$ & $0.31 \mathrm{~b}$ & $0.79 \mathrm{a}$ & $0.61 \mathrm{ab}$ & $4.19,0.047$ \\
Valine & 0.14 & 0.57 & 0.4 & 0.8 & $2.46,0.137$ \\
Conditional & & & & & \\
Arginine & $1.34 \mathrm{~b}$ & $2.86 \mathrm{a}$ & $1.88 \mathrm{~b}$ & $1.88 \mathrm{~b}$ & $4.48,0.04$ \\
Cysteine & $0.006 \mathrm{c}$ & $0.01 \mathrm{c}$ & $0.07 \mathrm{a}$ & $0.02 \mathrm{~b}$ & $46.18,<0.0001$ \\
Glutamine & 0.04 & 0.04 & 0.08 & 0.04 & $3.67,0.063$ \\
Glycine & $0.45 \mathrm{~b}$ & $1.04 \mathrm{a}$ & $0.41 \mathrm{~b}$ & $0.91 \mathrm{a}$ & $6.97,0.013$ \\
Proline & $1.89 \mathrm{~b}$ & $3.56 \mathrm{~b}$ & $52.3 \mathrm{a}$ & $44.1 \mathrm{a}$ & $11.02,0.003$ \\
Tyrosine & $1.8 \mathrm{~b}$ & $1.9 \mathrm{~b}$ & $2.8 \mathrm{ab}$ & $3.5 \mathrm{a}$ & $4.32,0.044$ \\
Serine & 0.002 & 0.002 & 0.003 & 0.001 & $0.41,0.75$ \\
Nonessential & & & & & \\
Alanine & 6.8 & 11.1 & 9.6 & 7.1 & $1.67,0.249$ \\
Asparagine & $0.29 \mathrm{bc}$ & $0.23 \mathrm{c}$ & $0.89 \mathrm{a}$ & $0.56 \mathrm{ab}$ & $9.76,0.005$ \\
Aspartic acid & 8.5 & 6.9 & 5.9 & 7.3 & $0.46,0.717$ \\
Glutamic acid & 0.48 & 1.56 & 0.97 & 1.57 & $3.88,0.064$ \\
\hline
\end{tabular}

Means followed by the same letter are not significantly different at the $0.05 p$ level

nutritional differences might have contributed PS and greater queen and colony losses esto the higher pathogen levels in colonies fed pecially for diet 1.

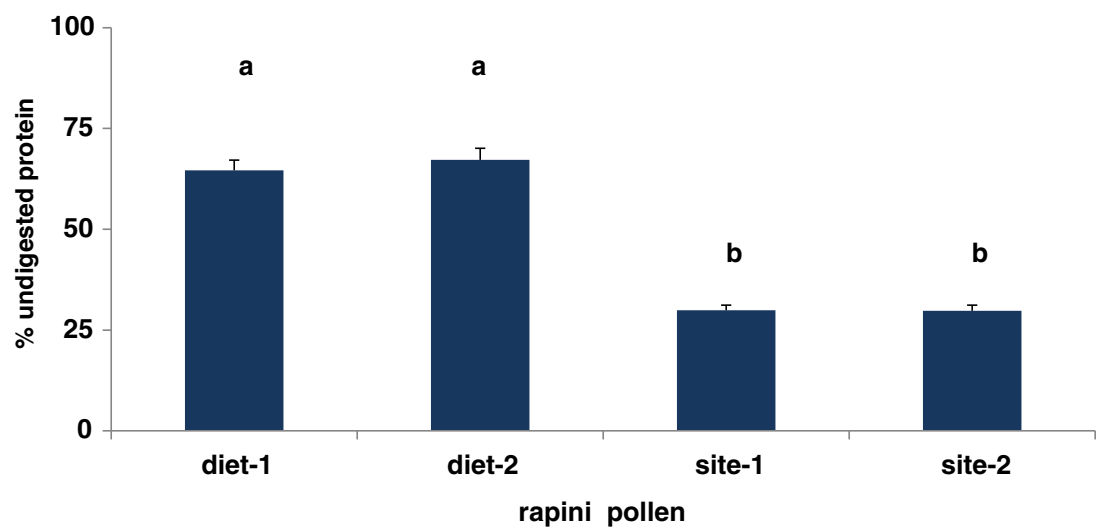

Figure 3. Percentage of undigested soluble protein $( \pm \mathrm{SE})$ in the hindgut of bees fed protein supplements (diets 1 and 2 ) or rapini pollen at two different sites (sites 1 and 2). Means followed by the same letter are not significantly different as determined by analysis of variance $\left(F_{3,29}=90.6, P<0.0001\right)$ followed by a Tukey's $\mathrm{W}$ procedure. 

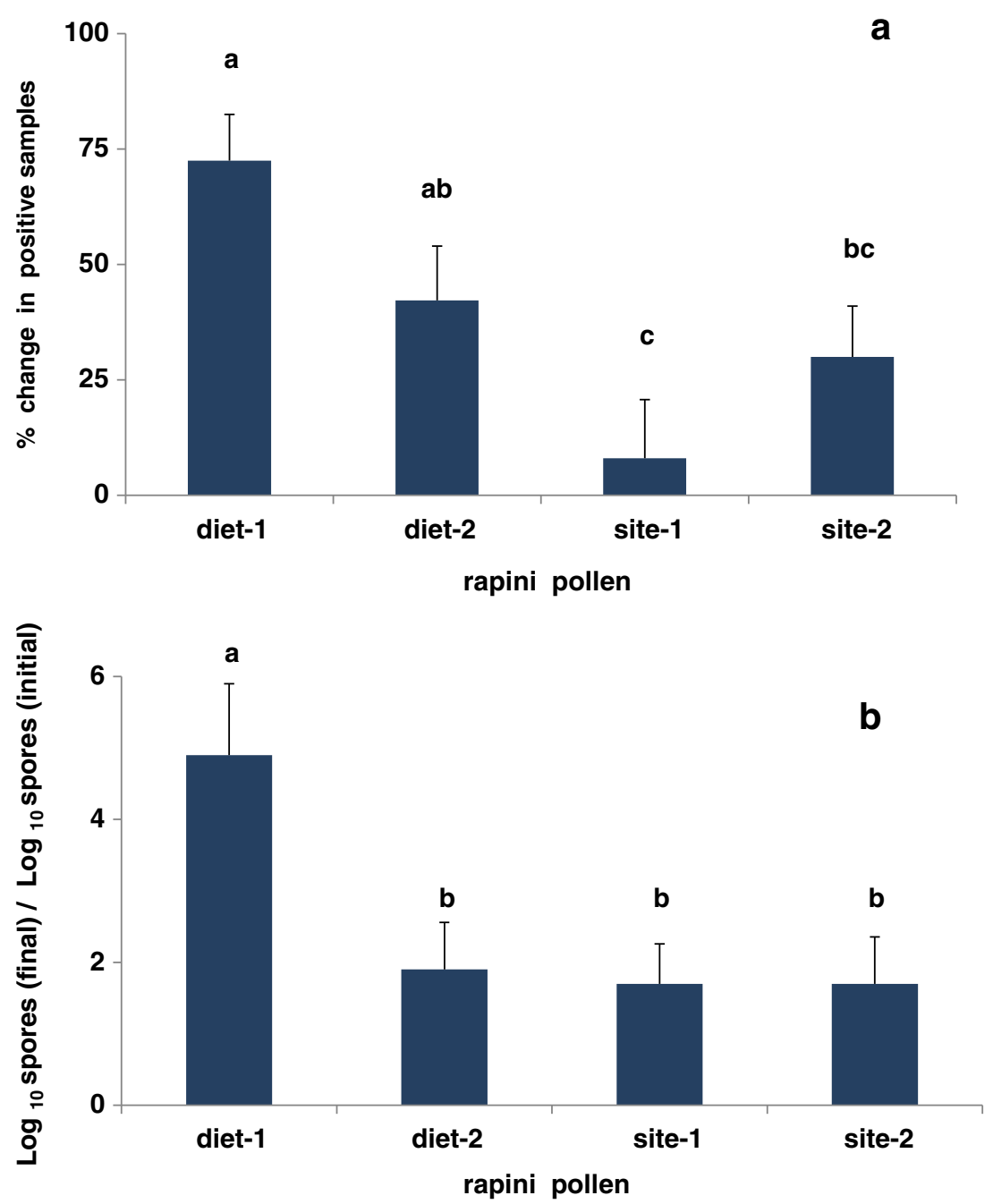

Figure 4. Average changes $( \pm \mathrm{SE})$ from the start to the end of the study in the percentage of samples with Nosema (a) from colonies fed protein supplements (diet 1 or 2) or rapini pollen at two different sites (sites 1 or 2). Average changes in the number of spores per colony $( \pm \mathrm{SE})$ are shown in $\mathbf{b}$. Means followed by the same letter are not significantly different as determined by a one-way analysis of variance followed by a Fisher's test (changes in the percentage of bees testing positive for Nosema: $F_{3,33}=5.19, P=0.005$, changes in spore numbers: $\left.F_{3,34}=4.10, P=0.014\right)$.

Pollen and beebread had similar soluble protein levels but differed in concentrations of certain AA. The beebread might have had pollen from sources other than rapini and caused the differences. However, similar results from controlled feeding studies have been reported $(\mathrm{Hu}-$ man and Nicolson 2006; DeGrandi-Hoffman et al. 2013). Possible reasons include the activity of proteolytic enzymes added to pollen during storage and metabolism by microbes in stored pollen
(Gilliam et al. 1989; Metges 2000). However, a recent study suggests that bacteria in stored pollen contribute to its preservation rather than predigestion or nutrient conversion (Anderson et al. 2014). Though the reasons for nutritional differences between pollen and beebread are not clear, both should be included in nutritional analyses of a pollen source (Roulston and Cane 2000; Di Pasquale et al. 2013). 


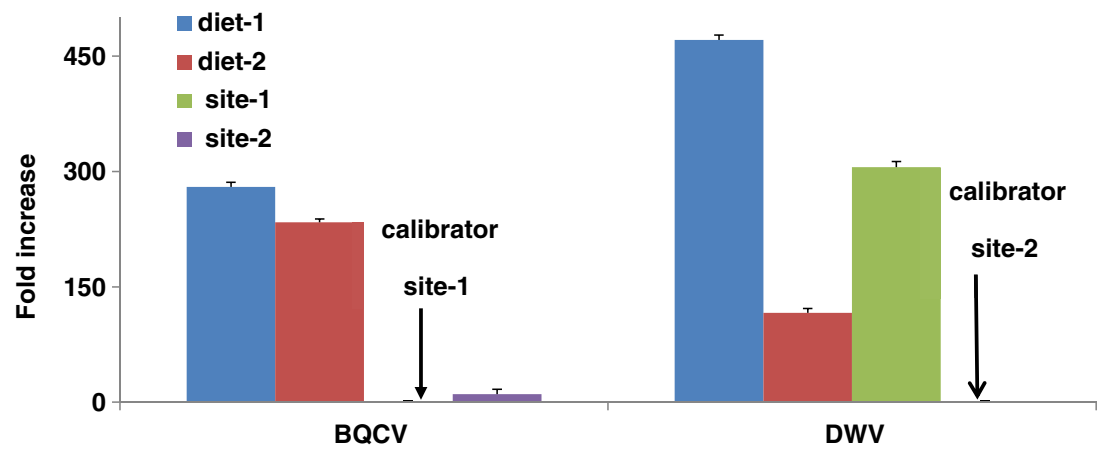

Figure 5. Fold increases $( \pm \mathrm{SE})$ in black queen cell virus (BQCV) and deformed wing virus (DWV) titers estimated by normalizing the titers $(\Delta \mathrm{Ct}=$ (virus titer for sample) $-(\beta$ actin $))$ for the treatment. $\Delta \mathrm{Ct}$ for site 1 was the calibrator for BQCV and site 2 for DWV. $\Delta \Delta \mathrm{Ct}$ is the difference between $\Delta \mathrm{Ct}$ for the treatment and the calibrator. The fold increase was calculated by $2^{-(\Delta \Delta \mathrm{Ct})}$.
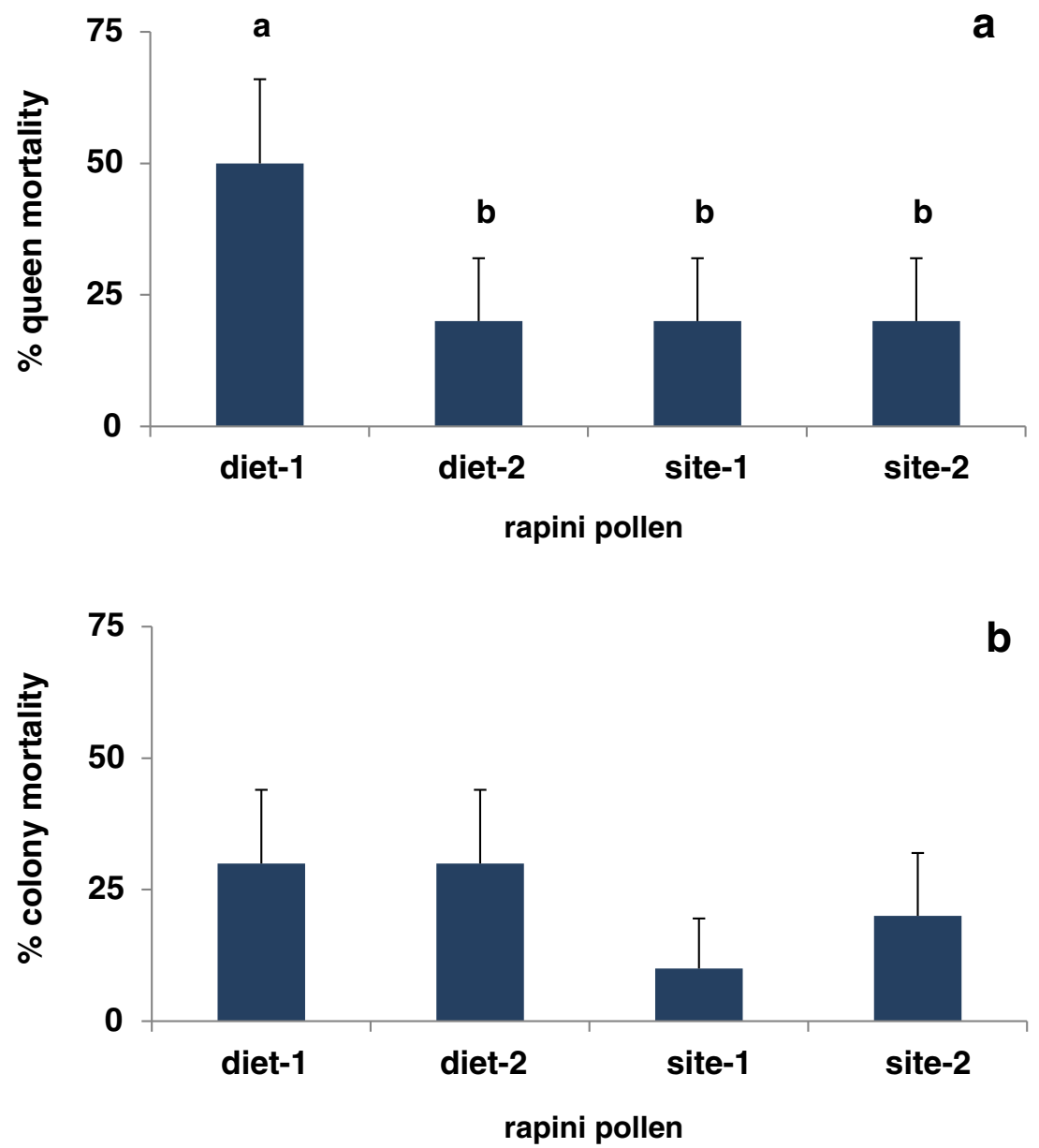

Figure 6. Percentages of queens $(\mathbf{a})$ and colonies $(\mathbf{b})( \pm \mathrm{SE})$ that died during the study period in colonies fed protein supplements (diet 1 or 2) or rapini pollen at two different sites (site 1 or 2). Queen losses were significantly higher in colonies fed diet 1 than those fed diet 2 or rapini (z-score $=1.84, P=0.03$ ). Colony losses were not significantly different (z-score $=1.4, P=0.07)$. 
Bees digested less of the protein in the PS than the pollen. Our estimates were similar to Wang et al. (2014) who reported digestion of $B$. rapa pollen to be about $67 \%$. In contrast, bees digested only about $35 \%$ of the protein in the PS. The differences might be that PS are difficult to digest because they contain soy or barley flour and eggs as protein sources, none of which are part of a bee's natural diet.

We found a significant relationship between Nosema levels and the amount of protein in the hindgut. Nosema replicates within midgut tissue (Higes et al. 2007; Dussaubat et al. 2012) and likely impairs digestion and nutrient absorption. Nutritional stress is exacerbated when there is Nosema infection because this microsporidia relies on the host to furnish energy for growth and reproduction (Mayack and Naug 2009; MartínHernández et al. 2011; Holt et al. 2013). Queen loss might also be more common because infected workers are less likely to feed nestmates (Naug and Gibbs 2009). In our study, colonies fed diet 1 had the greatest incidence of Nosema and the highest queen losses.

Though protein digestion was lower for PS than rapini pollen, hemolymph protein titers did not differ. Colonies fed PS had pollen traps on the entrance, but some pollen might have entered the hive since traps capture only a portion of what is collected. Though we are not certain that the bees fed exclusively on the PS, it probably was the primary protein source. Others have reported no effects of protein stress on soluble protein titers but stressed colonies produced less brood (Schmickl and Crailsheim 2001; Rueppell et al. 2008; Willard et al. 2011). In our study, brood production did not differ between colonies fed PS or pollen possibly because it occurred in the winter when brood rearing rates are low. In a study comparing PS with pollen in summer, brood rearing was lower in those fed PS (Hocherl et al. 2012).

Colony survival was similar between those fed PS and foraging on rapini. PS patties were replaced weekly, so the colonies were opened more often than those foraging on rapini. This difference did not seem to affect survival. However, we may have underestimated colony losses particularly in those fed diet 1 because we replaced lost queens. Queen loss in winter can be fatal to a colony. Even if a queen is reared, drones usually are not available for mating. Queen failure is a leading cause of overwinter colony loss (Brodschneider and Crailsheim 2010; vanEngelsdorp et al. 2010, 2013). Those losses might be associated with poor nutrition and higher pathogen loads that together compromise the care and health of queens.

Differences in AA concentrations between the PS and pollen may have contributed to the pathogen levels that we measured. All EAAs were present in the PS and pollen, but in some cases, concentrations were lower in the PS. The conditional AA cysteine and proline were much lower in both PS than in pollen. These AAs constitute large portions of certain antimicrobial peptides such as the cysteine-rich roylasin (Fujiwara et al. 1990) and the Apis-specific apidaecin that contains almost $30 \%$ proline (Casteel et al. 1990). Immune components respond in a nutrientspecific manner (Cotter et al. 2010). Whether the responses are driven by the nutritional demands of the immune traits, direct effects on immune gene expression, or indirect effects from diet based changes to microbial communities in the gut remains to be determined. Relevant to this final point is that gut microbial communities might differ considerably between bees feeding on PS and pollen (Pernice et al. 2014) and influence immunity and other measures of fitness.

For the past 7 years, winter colony losses in the USA have been between 22 and $36 \%$ (Steinhauer et al. 2014). The losses are due to many factors, several of which are related to the nutritional state of the colony. Feeding colonies PS in their current formulations does not appear to remedy problems of poor nutrition or reduce colony losses. In our study, we lost $30 \%$ of the colonies fed PS, which is within the range of annual winter losses in the USA. Though PS can help colony populations to build in the spring, our study indicates that PS alone might not sustain the health and survival of colonies over prolonged periods in the winter especially when colonies remain active. Under these conditions, planting forage for bees could be part of the solution for reducing colony losses. 


\section{ACKNOWLEDGMENTS}

The authors gratefully acknowledge Drs. Christina Grozinger and Amy Toth for their many helpful suggestions on earlier versions of this manuscript. We also thank the University of Arizona Agricultural Research Facilities for planting and caring for the rapini and the Almond Board of California for funding for this study.

\section{OPEN ACCESS}

This article is distributed under the terms of the Creative Commons Attribution 4.0 International License (http://creativecommons.org/licenses/by/4.0/), which permits unrestricted use, distribution, and reproduction in any medium, provided you give appropriate credit to the original author(s) and the source, provide a link to the Creative Commons license, and indicate if changes were made.

Les colonies d'abeilles disposant d'un approvisionnement naturel ont moins de pathogènes et présentent une survie hivernale plus élevée que celles nourries de compléments protéiniques

alimentation en pollen/ digestion/ acides aminés / Nosema / virus

Honigbienenvölker mit einer Nahrungsversorgung durch natürliche Sammeltätigkeit haben eine geringere Belastung mit Pathogenen und höhere Überwinterungsraten als Völker, die mit Proteinzusätzen gefüttert werden

Pollenernährung / Verdauung / Aminosäuren / Nosema / Bienenviren

\section{REFERENCES}

Alaux, C., Ducloz, F., Crauser, D., Le Conte, Y. (2010) Diet effects on honeybee immunocompetence. Biol. Letters $6,562-565$

Alaux, C., Dantec, C., Parrinelo, H., Le Conte, Y. (2011) Nutrigenomics in honey bees: digital gene expression analysis of pollen's nutritive effects on healthy and varroa-parasitized bees. BMC Genomics 12, 496

Anderson, K.E., Carroll, M.J., Sheehan, T., Mott, B.M., Maes, P., Corby-Harris, V. (2014) Hive-stored pollen of honey bees: many lines of evidence are consistent with pollen preservation, not nutrient conversion. Mol. Ecol. 23, 5904-5917
Brodschneider, R., Crailsheim, K. (2010) Nutrition and health in honeybees. Apidologie 41, 278-294

Casteel, P., Ampe, C., Riviere, L., Damme, J.V., Elicone, C., Fleming, M., Jacobs, F., Tempst, P. (1990) Isolation and characterization of abaecin, a major antibacterial response peptide in the honeybee (Apis mellifera). Eur. J. Biochem. 187, 381-386

Chan, W.T., Foster, L.J. (2008) Changes in protein expression during honey bee larval development. Genome Biol. 9, R156

Chen, Y.P., Higgins, J.A., Feldlaufer, M.F. (2005) Quantitative analysis of deformed wing virus infection in the honey bee, Apis mellifera L. by real-time RT-PCR. Appl. Environ. Microbiol. 71, 436-441

Cotter, S.C., Simpson, S.J., Raubenheimer, D., Wilson, K. (2010) Macronutrient balance mediates trade-offs between immune function and life history traits. Funct. Ecol. 25, 186-198

Crailsheim, K., Schneider, L.H.W., Hrassnigg, N., Buhlmann, G., Brosch, U., Gmeinbauer, R., Schoffmann, B. (1992) Pollen consumption and utilization in worker honeybees (Apis mellifera Carnica): Dependence on individual age and function. J. Insect Physiol. 38, 409-419

DeGrandi-Hoffman, G., Wardell, G., Ahumada-Secura, F., Rinderer, T.E., Danka, R., Pettis, J. (2008) Comparisons of pollen substitute diets for honeybees: consumption rates by colonies and effects on brood and adult populations. J. Apic. Res. 47, 265-270

DeGrandi-Hoffman, G., Chen, Y., Huang, E., Huang, M.H. (2010) The effect of diet on protein concentration, hypopharyngeal gland development and virus load in worker honey bees (Apis mellifera L.). J. Insect Physiol 56, 1184-1191

DeGrandi-Hoffman, G., Eckholm, B.J., Huang, M.H. (2013) A comparison of bee bread made by Africanized and European honey bees (Apis mellifera) and its effects on hemolymph protein titers. Apidologie 44, 52-63

DeJong, D., daSilva, E.J., Kevan, P.G., Atkinson, J.L. (2009) Pollen substitutes increase honey bee haemolymph protein levels as much as or more than does pollen. J. Apic. Res. and Bee World 48, 34-37

Di Pasquale, G., Salignon, M., Le Conte, Y., Belzunces, L.P., Decourtye, A., Kretzschmar, A., Suchall, S., Brunet, J.-L., Alaux, C. (2013) Influence of pollen nutrition on honey bee health: Do pollen quality and diversity matter? PLoS ONE 8(8), e72016. doi:10.1371/ journal.pone.0072016

Dussaubat, C., Brunet, J.L., Higes, M., Colbourne, J.K., Lopez, J., Choi, J.H., Martín-Hernández, R., Botías, C., Cousin, M., McDonnell, C., Bonnet, M., Belzunces, L.P., Moritz, R.F.A., Le Conte, Y., Alaux, C. (2012) Gut pathology and responses to the Microsporidium Nosema ceranae in the honey bee Apis mellifera. PLoS One 7(5), e37017

Field, A. (2005) Discovering statistics using SPSS $2^{\text {nd }}$ Edition. Sage Publications, Thousand Oaks, CA, USA

Fries, I., Chauzat, M.P., Chen, Y.P., Doublet, V., Genersch, E., Gisder, S., Higes, M., McMahon, D.P., Martin- 
Hernández, R., Natsopoulou, M., Paxton, R.J., Tanner, G., Webster, T.C., Williams, G.R. (2013) Standard methods for Nosema research. In: V Dietemann; J D Ellis, P Neumann (Eds) The COLOSS BEEBOOK: Volume II: Standard methods for Apis mellifera pest and pathogen research. J. Apic. Res. 51, doi:10.3896/ IBRA.1.52.1.14

Fujiwara, S., Imai, J., Fujiwara, M., Yaeschima, T., Kawashima, T., Kobayashi, K. (1990) A potent antibacterial protein in royal jelly. J. Biol. Chem. 265, 11333-11337

Gilliam, M., Prest, D.B., Lorenz, B.J. (1989) Microbiology of pollen and bee bread: taxonomy and enzymology of moulds. Apidologie 20, 53-68

Higes, M., Garcia-Palencia, P., Martin-Hernández, R., Meana, A. (2007) Experimental infection of Apis mellifera honeybees with Nosema ceranae (Microsporidia). J. Invertebr. Pathol. 94, 211-217

Hocherl, N., Siede, R., Illies, I., Gatschenberger, H., Tautz, J. (2012) Evaluation of nutritive value of maize for honey bees. J. Insect Physiol. 58, 278-285

Holt, H.L., Aronstein, K.A., Grozinger, C.M. (2013) Chronic parasitization by Nosema microsporidian causes global expression changes in core nutritional, metabolic and behavioral pathways in honey bee workers (Apis mellifera). BMC Genomics 14, 799

Human, H., Nicolson, S.W. (2006) Nutritional content of fresh, bee-collected and stored pollen of Aloe great headii var. davyana (Asphodelaceae). Phytochemistry 67, 1486-1492

Malone, L.A., Gatehouse, H.S. (1998) Effects of Nosema apis infection on honey bee (Apis mellifera) digestive proteolytic enzyme activity. J. Invertebr. Pathol. 71, 169-174

Martín-Hernández, R., Botías, C., Barrios, L., Martínez-Salvador, A., Meana, A., Mayack, C., Higes, M. (2011) Comparison of the energetic stress associated with experimental Nosema ceranae and Nosema apis infection of honeybees (Apis mellifera). Parasitol. Res. 109, 605-612

Mattila, H., Otis, G. (2006) Influence of pollen diet in the spring on the development of the honey bee (Hymenoptera: Apidae) colonies. J. Econ. Entomol. 99, 604-613

Mayack, C., Naug, D. (2009) Energetic stress in the honeybee Apis mellifera from Nosema ceranae infection. J. Invertebr. Pathol. 100, 185-188

Metges, C.C. (2000) Contribution of microbial amino acids to amino acid homeostasis of the host. J. Nutr. 130, 1857S-1864S

Morais, M.M., Turcatto, A.P., Francoy, T.M., Goncalves, L.S., Cappelari, F.A., DeJong, D. (2013) Evaluation of inexpensive pollen substitute diets through quantification of haemolymph proteins. J. Apic. Res. 52 , 119-121

Nabors, R. (2000) The effects of spring feeding pollen substitute to colonies of Apis mellifera. Am. Bee J. $140,322-323$

Naug, D., Gibbs, A. (2009) Behavioral changes mediated by hunger in honeybees infected with Nosema ceranae. Apidologie 40, 595-599
Nelson, D.L., Cox, M.M. (2012) Lehninger Principles of Biochemistry, Sixth Edition. Macmillan Higher Education

Peng, Y., D’Antuono, M., Manning, R. (2012) Effects of pollen and artificial diets on the hypopharyngeal glands of newly hatched bees (Apis mellifera L.). J. Apic. Res. 51, 53-62

Pernice, M., Simpson, S.J., Ponton, F. (2014) Towards an integrated understanding of gut microbiota using insects as model systems. J. Insect Physiol. 69, 12-18

Roulston, T.H., Cane, J.H. (2000) Pollen nutritional content and digestibility for animals. Plant Syst. Evol. 222, 187-209

Rueppell, O., Linford, R., Gardner, P., Coleman, J., Fine, K. (2008) Aging and demographic plasticity in response to experimental age structures in honey- bees (Apis mellifera L). Behav. Ecol. Sociobiol. 62, 1621-1631

Saffari, A., Keva, P.G., Atkinson, J.L. (2010) Palatability and consumption of patty-formulated pollen and pollen substitutes and their effects on honeybee colony performance. J. Apic. Sci. 54, 63-71

Schmickl, T., Crailsheim, K. (2001) Cannibalism and early capping: strategy of honeybee colonies in times of experimental pollen shortages. J. Comp. Physiol. A. 187, 541-547

Singh, R.P., Singh, P.N. (1996) Amino acid and lipid spectra of larvae of honey bee (Apis cerana Fabr) feeding on mustard pollen. Apidologie 27, 21-28

Smart, M.D., Sheppard, W.S. (2012) Nosema ceranae in age cohorts of western honey bee (Apis mellifera). J. Invertebr. Pathol. 109, 148-151

Steinhauer, N.A., Rennich, K., Wilson, M.E., Caron, D.M., Lengerich, E.J., Pettis, J.S., Rose, R., Skinner, J.A., Tarpy, D.R., Wilkes, J.T., vanEngelsdorp, D. (2014) A national survey of managed honey bee 2012-2013 annual colony losses in the USA: results from the Bee Informed Partnership. J. Apic. Res. 53, 1-18

Travers, B.E., Williams, M.R., Fell, R.D. (2012) Comparison of within hive sampling and seasonal activity of Nosema ceranae in honey bee colonies. J. Invertebr. Pathol. 109, 187-193

vanEngelsdorp, D., Hayes Jr., J., Underwood, R.M., Pettis, J.S. (2010) A survey of honey bee colony losses in the United States, fall 2008 to spring (2009) J. Apic. Res. 49, 7-14

vanEngelsdorp, D., Tarpy, D.R., Lengerich, E.J., Pettis, J.S. (2013) Idiopathic brood disease syndrome and queen events as precursors of colony mortality in migratory beekeeping operations in the eastern United States. Prevent. Vet. Med. 108, 225-233

Wang, Y., Ma, L.-T., Hang, X.-B., Yang, W.-R., Liu, F., Xu, B.H. (2014) Digestion of protein of two pollen types in China by the honeybee (Apis mellifera L). Apidologie 45, 590-600

Willard, L.E., Hayes, A.M., Wallrichs, M.A., Rueppell, O. (2011) Food manipulation in honeybees induces physiological responses at the individual and colony level. Apidologie 42, 508-518 